\title{
Social business for responding to natural disasters: a post-tsunami case study in Indonesian region
}

\author{
Teuku Aulia Geumpana \\ University of New South Wales \\ t.geumpana@unsw.edu.au \\ Mahfuz Ashraf \\ University of New South Wales \\ md.ashraf@unsw.edu.au \\ Rashadul Hasan \\ Research executive, Brainstorm Bangladesh ltd. \\ rhasan.official@gmail.com \\ Md. Munzur Morshed \\ Research executive, Brainstorm Bangladesh ltd. \\ morshed.munzur@gmail.com \\ Md. Uzir Hossain \\ Research executive, Brainstorm Bangladesh ltd. \\ hossainuzir@gmail.com \\ Anne Bunde-Birouste \\ University of New South Wales \\ ab.birouste@unsw.edu.au
}

\begin{abstract}
Disasters, mostly uncontrollable in nature, outbreak with devastating impacts throughout the world every year. Disasters might happen in any part of the world at any time. Though the aftermath of disasters negatively impacts all walks of life it usually creates casualties and affects the socio-economically vulnerable more severely than others. Following disasters, many volunteering organizations, government organizations and international aids collaborate to assist the overall populations affected, in particular the most disadvantaged. While these initial and immediate aid activities do certainly assuage problems for a short time, long term solutions actually depend on working with a sustainable approach, of which social business is one. In such situations, social business as an entrepreneurial tool can be a powerful strategy in alleviating the sufferings of this weaker section of the society with long term effect of ensuring sustainable development. Social business methods can be applied in various stages of a disaster management lifecycle (prior to disaster, during disaster and post-disaster operations). As in many other areas of sustainable development, social business plays a vital role for disaster management. In this paper, we present three case studies related to the impact of social business from the 2004 Indian Ocean Earthquake and Disaster management in Aceh province, Indonesia. Using a desk-research approach, we propose that social business within a disaster management context may aid the victims by promoting financial assistance in micro form at community level, increase stakeholders' collaboration in agriculture sector, resources distribution to reach more victims and encourage more community engagement at both rural and urban settings.
\end{abstract}

Keywords: Social Business, Social Problem, Disaster Management, Post-Tsunami.

\section{Introduction}

The earthquake and tsunami that hit the Indian Ocean countries in 2004, records as one of many major disasters that resulted in valuable lessons learned during the countries' various processes of recovery in social and business sectors. ${ }^{1}$ The lessons highlighted some good practices that will lead to 
lasting improvements in the future humanitarian assistance or disaster risk reduction. The global assessment report issued by UNISDR on Disaster Risk Reduction 2015 mentioned that the future of disaster risk management should be driven by multi stakeholders including business and financial sectors. $^{2}$ This recommendation is in line with the concept introduced by Nobel Peace Laureate Prof. Muhammad Yunus that social business can help populations most in need. The purpose of social business is to achieve one or more social objectives where the profit gained is always reinvested into the business once the original investments are reimbursed. ${ }^{3}$ In the context of disaster situations, the disaster survivors are victims in pressing need for multiple types of support. They are in situations of little or no primary health services, minimum standard of the living shelters, inadequate food and clean water, and living with significant psychological distress and trauma. ${ }^{4}$ Assisting survivors to regain livelihood as soon as possible is crucial so they can begin to recover from the loss and trauma they suffered from disaster. ${ }^{5}$

Social business can be a powerful solution to be included in relief operations during disaster emergency services. Incorporating a social business approach within various disaster management efforts will enable rebuilding with a holistic impact that will have ripple effects for constructing positive changes in disaster affected communities. The objective of this paper is to explore how social business has been used during and after disasters have struck; illustrating how a social business approach has helped to achieve sustainable development following the 2004 Indian Ocean earthquake and Tsunami.

The data sources of this research are secondary including websites, published reports, enewsletter and literature reviews. Some of the analysis is also based on the researcher's personal experiences during the relief's operation of the 2004 Indian Ocean earthquake and Tsunami in Aceh Province, Indonesia. The paper is organized as follows. In the next section we will discuss two general types of social business and their entrepreneurial scope. We then present three case studies from the 2004 Indian Ocean earthquake and Tsunami relief operations. We then analyze each case presented through a lens of social business principles and present a summary table at the end of our analysis section. Finally, we conclude the paper based on the analysis from the first section.

\section{Defining Social Business}

A Social Business is a non-dividend company that is created to address and solve a social problems. ${ }^{6}$ In a social business, the investors/owners can gradually recoup the money invested, but cannot take any dividends beyond that point. The purpose of the investment is purely to achieve one or more social objectives through the operation of the company, or business. No personal gain is to be obtained by the investors. The company must cover all costs and be financially sustainable, while achieving the social objective in sectors such as healthcare, education, poverty, environment, housing, climate urgency etc. $^{7}$

Social business earth, an international consulting and advisory firm based in Lugano, Switzerland, utilizes the model of social business to maximize the social impact of businesses, charities, philanthropies and government entities. According to social business earth there are mainly two types of Social Businesses as below:

Type 1: Focuses on businesses dealing with social objectives only e.g. the product produced is for the benefit of the poor or targeted to solve a specific social problem. Grameen-Danone is an example of Type I social business. Its product, Shokti Doi yogurt, produced in the plant in Bogra, Bangladesh, is fortified with micronutrients that are missing in the poor children. The concept of Shokti Doi yogurt is contribute to fighting malnutrition

Type 2 Social Business involves in profit maximising as long as it is owned by the poor and the disadvantaged communities, who can gain through receiving direct dividends or by some indirect benefits. For example, the product could be produced by the poor but exported to an international market while net profits would go towards workers' benefits. Examples of Type II social business are Grameen-Otto and Grameen Bank. However, Grameen Bank is both Type I and Type II social business, as it is owned by the poor people and it provides a financial service (e.g. microcredit loan without any collateral). Such scope was previously unavailable to poor people, especially women. 
In social business, the success of the business is measured based on the outcome/impact of the business on the people or environment in a given period, rather the amount of monetary profit made. Similarly, the sustainability of a social business also indicates the success of a social business when it runs independently without any external funding. ${ }^{3}$

\section{Aftermath of tsunami and scope for social business}

The devastating aftermath of the 2004 Tsunami, created from a severe earthquake of 9.0 magnitude, was not only confined to Indonesia and its adjacent areas. The impacts reached other continents, resulting in 160,000 dead, 90,000 missing and 700,000 displaced persons, with massive damages for fisheries, agriculture and commerce. ${ }^{8}$ Additionally, that Tsunami damaged the victim' means of earning livelihoods by destroying 58 percent of fishing boats, 66 percent of fishing equipment, and 77 percent of fishing harbors in Ache. Those effects and the subsequent aid influx have significantly altered the context of both local business activities and vulnerability. ${ }^{9}$

The disaster impacted on every aspect of human existence including the health, and welfare, physical and built environments, resulting in significant socio economic problems: loss of employment, significant health crisis, food crisis, infrastructure as well as psychological damage. ${ }^{10}$ Disasters impact include not only direct loss or damage but also indirect and secondary losses felt as impacts move from affecting people and buildings to socio-ecological systems such as markets and human health. ${ }^{11}$

In a scenario of such severe and numerous socio economic problems and resulting instability, we argue that a traditional profit-led business model is not sufficiently equipped to eradicate those problems. Similarly, traditional government systems are also supported by aid from the international community and cannot sufficiently address the problems. In the long run social businesses emerged with constructive solutions for sustainable development by impacting the affected community positively and comprehensively.

The unique approach of Social business inherently enabled addressing many of the care socio economic challenges resulting from or exacerbated by the Tsunami. ${ }^{12}$ The situation following the Tsunami required a type of business operations that would support social wellbeing through solving social problems both by paying dividends to the society and by fostering the pace of social entrepreneurship across the community such that income was generated and means of earning livelihood was ensured. With the idea of social business, Prof. Yunus has introduced a new dimension: a business approach with a different objective that does not strive to maximize profits, but rather strives to serve humanity's most pressing needs. ${ }^{13} \mathrm{~A}$ social business is a company that creates income for the poor or provides them with essential products and services like healthcare, clean water or clean energy and aims to be financially selfsustaining with sustainable social impact. ${ }^{14}$

Table 1: Seven principles of Social Business

Principle 1: The business objective will be to overcome poverty, or one or more societal problems (such as education, health, technology access, and environment) which threaten people and society, rather than profit maximization.

Principle 2: Financial and economic sustainability.

Principle 3: Investors get back their investment amount only. No dividend is given beyond investment money.

Principle 4: When investment amount is paid back, company profit stays with the company for expansion and improvement.

Principle 5: Gender sensitive and environmentally conscious.

Principle 6: Workforce gets market wage with better working conditions.

Principle 7: ... do it with joy.

The framework of a social business is based on seven principles (table 1), some of which inherently align with various Sustainable Development Goals (SDGs) (figure 1). For example, one of the business objectives (principle 1) of a social business is to overcome poverty, or problems of education, health, and environment which threaten people and society; this is the core of the SDG goals (goal 1). Similarly, principle 2: financial and economic sustainability aligns with SDG goal 8. In this sense it can be said that social business and SDG goals complement each other; metaphorically they are like brick-and-cement strategy where the 
SDG goal identifies a socio economic area to be developed and social business executes the development.

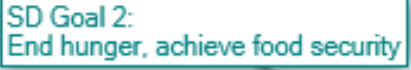

Figure 1: Alignment of social business principles (1, 2 and 5) with various Sustainable Development Goals

\section{Case studies}

Following the 2004 Indian Ocean earthquake and Tsunami, this paper explores how social business contributed to providing after-Tsunami management and development-support related to social problems. The paper studies three social business projects below:

\subsection{Case study 1: Urban farming}

Urban farming is an agricultural prioject within or near a city; it generally involves skills, expertise and innovation in cultivation and food processing. In Jakarta, the case in question was led by Bina Swadaya, a self-reliance development foundation. The activity of Urban Farming project actually lies in the effort to contribute to food security, increasing the income of the surrounding community as well as recreational and hobby facilities. Bina Swadaya focussed on urban farming after the Tsunami broke out. Bina Swadaya is a Self-Reliance Development Foundation that is a people-centred development organization carrying out a range of services oriented towards raising the economic status of the poor using self-help groups approach. ${ }^{14}$ Through this program Bina Swadaya strived to become an organization of excellence in empowering the people throughout Indonesia solidarity and selfreliance. Bina Swadaya started its work for the ETESP (Earthquake \& Tsunami Emergency Support Project) in November 2005 and ended in 2008.

The Urban Farming project implemented by Bina Swadaya involved planting chili and leaf vegetables in 5 areas of DKI Jakarta Province. With this urban farming program, Bina Swadaya assisted for the food needs by optimizing existing land, and 
realizing an increase in family food sterility, especially on chili and vegetables. During that time, this organization constructively overhauled the devastated area of Tsunami by fostering entrepreneurships, alleviating poverty, supporting means of livelihood, ensuring foods and many other necessities. $^{15}$

As mentioned earlier, the agriculture and fisheries were completely devastated. Hence the livelihood of those people depending on agriculture and fisheries, was severly impacted. The urban farming project enabled those communities in Jakarta to revive their livelihoods through a social business approach. ${ }^{15}$ Bina Swadaya facilitated a total of 2173 SHGs (Self Help Groups) after Tsunami through urban farming. Of those 543 SHGs were in agriculture sector. Until today, a total of 106,698 people of whom $39.3 \%$ were women were benefited by Bina Swadaya's urban farming project. $^{15}$

\subsection{Case study 2: Trubus Shop}

Trubus Shop in the Bintaro area is another social business project. It provides agriculture and fish products and as well as fruit seeds. The Bintaro region has great agricultural potential, with many families cultivating fruit trees, however often the seeds need to be sourced from significant distances. To strengthen a capacity to develop a market in Bintaro, Trubus Shop was initiated a social business model approach across the area.

In Bintaro, the Trubus Shop, initiated a collaboration with Leo Sutrisno when he allowed to use his land to build the Plant Supermarket and Trubus Fresh shop. Leo Sutrisno provided the land for a shop in Bintaro. Shopr provided seeds at $\mathrm{s}$ reduced rate along with other agricultural maintenance equipment as well as providing a space where local residents could sell their produce. Trubus Fresh became an alternative for Bintaro and surrounding residents to shop for various fresh fruits. The Trubus Fresh became the first fruit shop owned by the Trubus Shop network throughout Indonesia, and created many jobs.

The Trubus Shop also engaged with the fisheries sector. They began by setting up a consultant team which engaged with community members to register and analyse complaints, linking with existing local structures to resolving issues at the village and subdistrict levels. ${ }^{\mathbf{1 6}}$
Trubus Shop then provided products and processes which helped 1051 listed fish suppliers. For better execution of those activities, 383 village mobilization facilitators were recruited and trained, 286 irrigation facilitators and 307 community facilitators for fisheries resulted in poverty reductions and job creation - a development that aligns with SDGs.

\subsection{Case study 3: YAMIDA Microfinance}

Dhuafa Foundation Partner (Yayasan Mitra Dhuafa) or better known as YAMIDA was an organization that had many activities in promoting and implementing microfinance programs at the community level in Aceh. ${ }^{17}$ In 2005, several months after the shocking disaster of earthquake and Tsunami in Aceh Province, Indonesia, the Grameen Foundation worked with Yayasan Mitra Dhuafa (YAMIDA) to expand financial services to more poor women throughout the Aceh province. YAMIDA was one of the program partners of Grameen Bank Foundation during after the 2004 disaster for microfinancing using social business scheme. $^{18}$

In the post Tsunami situation, to manage the demand of microfinance loans, a microfinance management information system (M2) was initiated by the Grameen Foundation to track fund disbursement and how it is used at the communities. The system was run by Yamida volunteers in each branch, and the software package was developed in the Philippines by the firm Southern Horizons. Even though the system was developed and serviced from the Philippines, a local technical consultant was hired to ensure the system functions as intended and communicate with the consulting firm in Philippines to resolve any technical bugs found during its deployment in the field.

Yamida opened six new branch offices in the four most devastated districts in the Nanggroe Aceh Darussalam (NAD) province, giving more than 17,500 Tsunami-affected women access to much-needed financial services. ${ }^{19}$ YAMIDA began operating as a microfinance organization in Aceh through support from the Grameen Foundation USA and Grameen Trust Bangladesh. Between 2005 to 2008, the Grameen Foundation provided USD 200,000 in funding, USD 160,000 as zero percent loans to clients and a USD 35,000 grant for operating expenses. ${ }^{20}$ 
The M2 system that was initiated by the Grameen Foundation to support the loan tracking and monitoring of the microfinance program being run by YAMIDA in Aceh province. The principle working concept of the microfinance program was to start with small loan to one community. A successful program would then generate income and the loan would be repaid enabling a new loan to be available to another community with the same concept, The processes would continue to reach all the communities in the area. With the M2 system in place, the microfinance program could be easily monitored and tracked. Community could check loan instalment that they have received or remaining balance that they have to repay. Progress of the project was also monitored corresponded to the fund disbursed in the communities.

\section{Analysis through the lens of social business}

The three cases of social business described in the previous section each relates to one or more principles from the 7 social business principles. Different solutions offered by social businessnd its contribution to disaster management illustrate effective solutions to addresso social problems either from organizational or community perspective. After any disaster breaks out, it is found that following forms of action can reduce the severity of the impact. The social business projects discussed above helped the people affected by the Tsunami in Indonesia from the following points of view:

Cash-for-work: the three social business programs created employment, where people were empowered through work. All three projects created jobs and provided cash for work.

\section{Micro-credit/financing:}

YAMIDA Microfinance helped the local populace by providing financing them to start their business again, or purchase new equipment that had been lost. These take the form of low interest loans to Tsunami-affected people wishing to start, or restart some enterprise.

Training: In Social business many training programs are on offer. They include entrepreneur, management, accounts and business development training, a wide range of agricultural and skills development programs, quality control and marketing training. The Trubus Shop projects helped Tsunami-affected people by offering many such training opportunities.

Infrastructure development: The Trubus Shop helped in reconstructing fishing harbors, building marketplaces and shops.

Market facilitation: Urban farming helped people in producing agricultural products and connected with appropriate markets, e.g. connecting producers of vegetables with shops in large hotels, and with retailers in the big cities.

Organisational strengthening: Social business programs strengthened and built capacity in existing agriculture and fishery sector and enabled the formation of new production cooperatives and societies. The social business projects also provided support in the form of organisational management/capacity training.

Advocacy: There is very little advocacy work on livelihoods as such, but a lot of advocacy work on issues that affect livelihoods, such as the empowerment or job creation issue.

Community Engagement: Community mapping was one of the activities by all the three social business. It helped to highlight on what areas would the locals want to develop and how would they wanted to pursue; from the creation of household to their village to access of safe water.

The following table 2 summarizes the above discussion. The table will layout the three case studies that address the social problems at the community levels. At the bottom of the table, we linked the relationship between the solutions offered to the 7 principles of social business. 


\begin{tabular}{|c|c|c|c|}
\hline & Urban farming & Trubus Shops & YAMIDA Microfinance \\
\hline $\begin{array}{l}\text { Problem } \\
\text { Addressed }\end{array}$ & $\begin{array}{l}\text { Economic status for the } \\
\text { farmers and women was } \\
\text { poor. Possibility of } \\
\text { having duplication or } \\
\text { unequal distribution of } \\
\text { economic support. } \\
\text { Additionally, there was } \\
\text { lack of trust and low } \\
\text { confidence of fund } \\
\text { disbursement from } \\
\text { donors after the period } \\
\text { post-disaster. }\end{array}$ & $\begin{array}{l}\text { Lack of community } \\
\text { driven participation and } \\
\text { financial support for } \\
\text { rebuilding program } \\
\text { agriculture and as well as } \\
\text { fishing sector. }\end{array}$ & $\begin{array}{l}\text { There was a need to } \\
\text { expand financial services } \\
\text { to more poor women } \\
\text { throughout the Aceh } \\
\text { province. }\end{array}$ \\
\hline $\begin{array}{l}\text { Solution } \\
\text { offered }\end{array}$ & $\begin{array}{l}\text { Urban farming brought a } \\
\text { people-centred social } \\
\text { business model for } \\
\text { carrying out a range of } \\
\text { services oriented towards } \\
\text { raising the economic } \\
\text { status of the poor using } \\
\text { self-help groups } \\
\text { approach. }\end{array}$ & $\begin{array}{l}\text { - Using social business } \\
\text { model Trubus Shops } \\
\text { were setup across the } \\
\text { area. } \\
\text { - It created a long term } \\
\text { sustainable solution for } \\
\text { the people who plant } \\
\text { fruit trees in the yard of } \\
\text { his house and as well as } \\
\text { the people involved in } \\
\text { fishing. }\end{array}$ & $\begin{array}{l}\text { Expand financial loans } \\
\text { to more poor women in } \\
\text { form of microfinance at } \\
\text { the community level. } \\
\text { - The loans were repaid } \\
\text { and further re-loan to } \\
\text { other communities. }\end{array}$ \\
\hline $\begin{array}{l}\text { Alignment } \\
\text { with } 7 \text { social } \\
\text { business } \\
\text { principles }\end{array}$ & $\begin{array}{l}\text { Aligns with principle number } \\
\text { 1, 2, } 5 \text { and } 7 . \\
\text { - } \quad \begin{array}{l}\text { To overcome poverty } \\
\text { that are caused by losing } \\
\text { business and damage in } \\
\text { property post disaster }\end{array} \\
\text { - Achieving economic } \\
\text { sustainability through } \\
\text { micro financing projects } \\
\text { - Targeted beneficiaries } \\
\text { were mostly women } \\
\text { - Community driven } \\
\text { solutions to establish } \\
\text { micro financing project } \\
\text { in joyful manner }\end{array}$ & $\begin{array}{l}\text { Aligns with principle number } \\
\text { 1, 2, } 6 \text { and } 7 . \\
\text { - } \quad \text { To overcome poverty } \\
\text { that are caused by losing } \\
\text { business and damage in } \\
\text { property post disaster } \\
\text { - } \quad \begin{array}{l}\text { Achieving economic } \\
\text { sustainability through } \\
\text { micro financing projects }\end{array} \\
\text { - Workforce gets market } \\
\text { wage with better } \\
\text { working conditions. } \\
\text { Community driven } \\
\text { solutions to establish } \\
\text { micro financing project } \\
\text { in joyful manner }\end{array}$ & $\begin{array}{l}\text { Aligns with principle number } \\
\text { 1, 2, 3, } 4,5 \text {, and } 7 . \\
\text { - } \quad \begin{array}{l}\text { To overcome poverty } \\
\text { that are caused by losing } \\
\text { business and damage in } \\
\text { property post disaster }\end{array} \\
\text { - Achieving economic } \\
\text { sustainability through } \\
\text { micro financing projects } \\
\text { - } \quad \begin{array}{l}\text { Loans are returned to } \\
\text { investor with no } \\
\text { dividend }\end{array} \\
\text { Returned loan will be } \\
\text { used for other } \\
\text { community to start } \\
\text { another micro financing } \\
\text { project } \\
\text { Targeted beneficiaries } \\
\text { are women } \\
\text { Community driven } \\
\text { solutions to establish } \\
\text { micro financing project } \\
\text { in joyful manner }\end{array}$ \\
\hline
\end{tabular}




\section{Conclusion}

The major limitation of this research is that the data is derived from secondary reports, desk research and focus only on specific cases in Indonesia. It does however open future research opportunities for research in policies and management of disasters in developing countries. However, in exploring the three case studies where a social business model was implemented to address the challenges of postdisaster management in a particular social setting, we find that the use of social business supported social and economic resilience at community levels in sustainable manner. Unlike sheer dependency on donations for social and economic resilience in postdisaster situations, social business approaches enable communities to be empowered and become self-dependent by sustaining their means of livelihood and creating job opportunities. In our case studies we found that the wider scope of social business creates opportunity for sustainable development in the sectors which are closely mingled with the livelihood of the victims of disasters, such as agriculture, community business and microfinancing. The concept of entrepreneurship can be powerful strategy in alleviating the sufferings of this weaker section of the society. The establishment of social business projects by microfinance helps the victims to earn a sustainable income based on their skills and expertise.

Our contribution from this paper is to provide examples of Social Business and highlight its role towards post- disaster recovery, particularly supporting sustainable development for the weaker sections of a society. Some of these case studies may help or guide international aid agencies to better plan, monitor and evaluate future project development and implementation to ensure sustainable development options . The results from this article will also benefit other countries in similar contexts where social business works with in collaboration governments and NGOs involved in post-disaster development projects to attain the social objectives in sustainable manner. Similarly, the Bi-lateral and multi-lateral agencies which determine funding for development projects (UN, World Bank, Asian Development Bank) could fund social business projects for sustainable solutions for the victims.
The lesson learned from this research will enable the policy makers to rethink the scope of social business, and to facilitate social business projects by taking into account the social problems created in post-disaster situation. The authors propose that this study can help encourage multidisciplinary research (across environment science, social science, disaster, logistics and operation management, and finance) to tackle some difficult problems created after environment and natural disasters, and suggest that future research should be implemented to find the alignment among social business, post-disaster context and sustainable development goals (SGDs) to ultimately create a more effective and comprehensive solution.

\section{Acknowledgement}

The previous version of this research has been presented and published into the Global Social Business Academia Conference in Berlin 2015. We duly acknowledge the anonymous reviewers for the comments. 


\section{References}

1 K. Mangkusubroto, "Analisis Dinamika Kolaborasi antara Badan Rehabilitasi dan Rekonstruksi Aceh dan Nias (BRR) dengan Lembaga Donor Pasca Tsunami 2004 menggunakan Drama Theory (Translated: Collaboration Dynamics Analysis between the Rehabilitation and Reconstruction of Aceh and Nias Agency (BRR) with Multi Donors post the Tsunami in 2004 using the Dramatic Theory)", Technology Management Journal, Vol. 10 no. 1, 2011, pp. 42-63.

2 UNISDR, 'Making Development Sustainable: The Future of Disaster Risk Management', Global Assessment Report on Disaster Risk Reduction, Geneva, Switzerland, 2015.

3 M. Yunus, 'Social Business', 2007. Retrieved from http://www.muhammadyunus.org/index.php/socialbusiness/social-business.

4 H. Masyrafah and J. M. McKeon, "PostTsunami Aid Effectiveness in Aceh", Wolfensohn Center for Development Working Paper, no. 6, 2007.

5 S. Doocy, C. Robinson, C. Moodie and G. Burnham, 'Tsunami-related injury in Aceh Province, Indonesia', Global public health, Vol. 4, no. 2, 2009, pp. 205-214.

6 T. Berry and L. Marks, 'The dream of the earth' (Sierra Club Books; Vol. 2, San Francisco, 1988).

7 M. J. Epstein and A. R. Buhovac, 'Making sustainability work: Best practices in managing and measuring corporate social, environmental, and economic impacts' (Berrett-Koehler Publishers, 2014).

8 R. Shaw, B. Alexander, C. Chan-Halbrendt and W. Salim, 'Sustainable livelihood considerations for disaster risk management: implications for implementation of the Government of Indonesia Tsunami recovery plan.' Disaster Prevention and Management: An International Journal, Vol. 15 no. 1, 2006, pp. 31-50.

9 B. Alexander, C. Chan-Halbrendt and W. Salim, 'Sustainable livelihood considerations for disaster risk management: implications for implementation of the government of Indonesia tsunami recovery plan', Disaster Prevention and Management: An International Journal, Vol. 15, no. 1, 2006, pp. 31-50. https://doi.org/10.1108/09653560610654220.

10 D. Lewis, N. Hodge, D. Gamage, and M. Whittaker, 'Understanding the role of technology in health information systems', Pacific health dialog, Vol. 18, no. 1, 2012, pp. 144-154.

11 J. Birkmann, P. Buckle, J. Jaeger, M. Pelling, N. Setiadi, M. Garschagen, ..... and J. Kropp, 'Extreme events and disasters: A window of opportunity for change? Analysis of organizational, institutional and political changes, formal and informal responses after mega-disasters', Natural Hazards, Vol. 55, no. 3, 2010, pp. 637-655. https://doi.org/10.1007/s1 1069-008-9319-2.

12 M. Yunus, 'Building social business: The new kind of capitalism that serves humanity's most pressing needs', In: Public Affairs. (Public Affairs, 2010).

13 M. Yunus, B. Moingeon, and L. LehmannOrtega, 'Building social business models: Lessons from the grameen experience', Long Range Planning, Vol. 43 no. 2-3, 2010, pp. 308-325. https://doi.org/10.1016/j.lrp.2009.12.005.

14 A. Tschumi, 'Community Health Workers Get Training' In: IRC Aceh Newsletter. (IRC Aceh Newsletter, November, 2005).

15 H. Soesangobeng, Z. Fuady and J. Nicolas, 'Complaint Handling in the Rehabilitation of Aceh and Nias: Experiences of the Asian Development Bank and Other Organizations', Metro Manila: Asian Development Bank, 2009.

16 United Nations Office for Disaster Risk Reduction (UNISDR).

17 A. Voets, M. De Brune, I. Wirawan, A. A. Ramly, N. Bannister and T. Geumpana, 'Community Driven Regeneration' In: IRC Aceh Response. (IRC Aceh Response, 2006).

18 U. Grameen Foundation, 'Recovery from the Tsunami Disaster: Poverty Reduction and Sustainable Development through Microfinance', Alex Counts and L. Collins (Eds.). (Washington, D.C USA: Grameen Foundation USA, 2005).

19 E. Porterfield, 'Indonesia: Creating new economic opportunities in tsunami-affected communities of Aceh: American Red Cross', 2008.

20 L. Curtis, 'MICROCAPITAL STORY: YAMIDA Opens First Microfinance Branches in 
Aceh Jaya, Indonesia in Partnership with the American Red Cross and the Grameen Foundation as Part of Ongoing Tsunami Relief Efforts', (2008).

Retrieved from http://www.microcapital.org/. 